\title{
The Design and Identity of Batik Tulis Product Selected of Batik Manufacturers in Klang Valley
}

\author{
Ahmad Hakim Abdullah \\ Faculty of Creative Technology and Heritage, Universiti Malaysia Kelantan \\ 16300 Bachok, Kelantan, MALAYSIA \\ Author email: desamurni15@gmail.com
}

Published: 28 September 2020

\begin{abstract}
Batik Tulis in the Klang Valley has motif and pattern design that identified its own identity. The purpose of this study is to find out the development of the Batik tulis industry in the Klang valley from year 2000 until 2018. Next, it also to study the design and identity of the Batik tulis motif and pattern in the Klang valley from year 2000 until 2018. This study used several methods and approach for data collection consist of interviews, observations and photo documentation. Three Batik tulis manufacturers in Klang Valley have been identified in carrying out this study. The data were then analysed using analytical design approach. The findings showed that, each product of Batik tulis has a uniqueness in terms of subject matters as well as assertions in pattern and designs used. The development of the Batik tulis industry has been changed in terms of design according to the demand of batik users themselves who want differentiation in the design concept of batik products. Most of the batik products in this Klang valley are more focused on the concept of modern and contemporary design. It involves the use of colours, the type of fabrics and the selection of motifs characterized by flora and fauna in modern style. In conclusion, Batik tulis designs and identity in the Klang Valley from year 2000 until 2018 are still retain the originality of the flora and fauna motifs themselves but have made the design of the traditional style to a more modern and contemporary design. However, the design aspect of Hand drawn Batik products in the Klang Valley today needs to be disclosed to the public so that, it can maintain the textile arts, especially the Batik tulis as a Malay textile heritage.
\end{abstract}

Keywords: Klang Valley, batik Tulis, Design, Manufacturer, Identity

eISSN: 2550-214X (C) 2020. The Authors. Published for Idealogy Journal by UiTM Press. This is an Open Access article distributed under the terms of the Creative Commons Attribution-NonCommercial-NoDerivatives License (http://creativecommons.org/licenses/by-nc-nd/4.0/), which permits non-commercial re-use, distribution, and reproduction in any medium, provided the original work is properly cited, and is not altered, transformed, or built upon in any way.

\section{INTRODUCTION}

\subsection{Background}

The Application of the batik tulis is popular especially among the Malay community. Researchers reviewed in terms of features and identity in the Klang valley this batik. researchers have chosen three producers of batik tulis in the Klang Valley the Master Wan Batik, Abas Sal Batik and also Chanting Creation. In the meantime, the three producers this batik tulis produced in early 2000 to today. Company Master Wan this Batik manufacturers batik in early 2000. In addition, Master Wan Batik is also as manufacturers, Dealers, suppliers and the batik tulis Stockist also in the Klang Valley this. the company's focus on batik block and batik tulis compared with stencils.

Batik manufacturer is Abas Sal Batik in the Klang Valley was established in the year 1999 this year many batik tulis in produce with such as Cloth products, Install Bracket but Shirt more traditional concept of identity to design more to flora with compact Arrangement. Further, the company is the manufacturer of the batik Chanting Creation was manufacturer in the Klang Valley with modern contemporary concept. The company more identity with an abstract, and Flora and Fauna with modern concepts. In the meantime, many companies focus on Chanting Creation batik tulis product to the cloth 
Robes, and Men t-shirts. Design changes was in particular because it is in accordance with current needs and also time changing.

Overall, the adoption of batik tulis in the Klang Valley is still lacking identity exposures and new features concepts to the community. In terms of changes to design batik tulis in the Klang Valley still retain the identity of the flora and fauna motifs in modern contemporary concept. In addition, identity batik tulis in the Klang Valley this many ideas generated from flora motifs. In 2000 most of handmade is more to repeat design flora which many repetitions with no motive not more emphasis in the design. In the year 2004 to 2009 many designs almost the same design in 2000. Then, in 2010 design batik tulis in this more aggressive with a relatively harmonious use of colour and pattern that is more towards modern contemporary. In addition, also during the year, use of colour are also more modern design with a relatively prominent. Additionally, the design in 2015 to date it more to design flora with colours and modern products. Hand-drawn identity in the Klang Valley in the year 2015 until now is more focus on the value of uniqueness and aesthetics to the distinctive motifs of flora.

Currently, changes in design patterns from the year 2000 till 2018 also change according to the changes in a particular place in accordance with the requirements of the current market designs. in addition, hand-drawn identity in the Klang Valley is more concept concepts design not to meet the overall space on each product that batik tulis. Additionally, the identity and the concept of batik tulis in the Klang Valley is not only that in terms of the acceptance of the community is increasing than ever before who only know traditional batik was only popular in this era period to the year 2000. The batik patterns also existed in the Klang Valley are also quite clearly exhibited identity motif especially motifs of flora and fauna, but still have the elements of a modern contemporary concept.

\subsection{Problem Statement}

According to Sasaliza Mohd Sirin (2017), not many people in the community of Klang Valley know that they have their own batik identity if compared to Kelantan and Terengganu, batik in Klang Valley tend to bear more traditional features such as flora and fauna motif. Even though the time has change. Currently in Malaysia, the number of people wearing batik has reduced because not many make it a practice to wear traditional clothes. This is especially true in Klang Valley and the Federal District. In addition, those who live in the city don't get extensive knowledge about batik tulis. For government employees who work there are not many who promote the practice of wearing batik every Thursday.

Some of them may wear it because they already have a sense of love for their Malaysian heritage. Besides that, the availability of batik is also quite rare when compared to non-traditional clothing. In addition, those in the city may not be able to appreciate the fact that batik is a symbol of Malay heritage. In terms of designs and patterns, there have been changes in both, as well as colour, from the year 2000 till now. The availability of various colours and motifs can be used as leverage to commercialise batik in the market. But many who wish to highlight themselves with traditional batik clothing may find this difficult to do as, powered by the latest trends, Western brands continue to dominate and in turn, make it difficult for the batik industry to grow internationally. Normally, urban areas like the Federal Territory of Kuala Lumpur and Selangor not many people wear batik in their daily lives. In addition, this lack of presence will result in a lack of interest and understanding in batik for those who live in the city. The Malaysian batik industry is getting bleak and it is possible that it will uplift if there are no more vigorous efforts to restore its glory as a national heritage. This situation is certainly a nuisance not only for batik lovers, but also batik entrepreneurs who saw the dumping of their batik products in Klang Valley due to the less than favourable response. (Siti Aishah Yusoff, 2014) This problem exists because people view batik as traditional clothing that is only worn by elders. This is because the patterns and designs of batik are not up-to-date with current trends. Young people are more interested in more relaxed, trendy and modern styles. In addition, the colours of batik today are also the same as before, that is, chocolate, black and white. (Hafiz, 2012). 


\subsection{Aim}

To show the design identity and development of batik tulis in Klang Valley from 2000 until 2018.

\subsection{Research Objective}

1. To study the design development of batik tulis in Klang Valley from 2000 until the end of 2018

2. To identify the design concept and features of batik tulis in Klang Valley from 2000 until 2018

\subsection{Research Question}

1. What are the developments in design of batik tulis in Klang Valley from 2000 until 2018 ?

2. What are the design concept and features of batik tulis in Klang Valley from 2000 until 2018 ?

\subsection{Statement of Significance}

This subject is not only interesting and relevant to my studies. it is also my way of spreading love and appreciation for batik tulis to our current generation, especially those residing in the Federal Territory of Klang Valley. More than that, I want to show that Kelantan and Terengganu are not the only Malaysian states with attractive batik Klang Valley too produces batik with its own identity. In my review, I will highlight the value of every development made by the batik industry in the Federal Territory of Kuala Lumpur and Selangor. Batik in the Klang Valley produce batik with their own style and identity too. The motive behind this study is to examine the development of batik-making from 2000 till this very day. Research has identified that hand-drawn batik in Klang Valley has experienced changes up to modern times, so it is important to analyse the changes made from 2000 to 2018.is shows that not only Kelantan and Terengganu and produced with attractive batik identity but Klang valley also produces batik with its own identity.

As a result of batik tulis research in terms of the new concept and identity in Klang Valley it will create awareness to the community that in Klang valley this batik tulis have unique aesthetic value not only batik manufacturing from Kelantan and Terengganu. In addition, also as a result of this study will also give effect to agree to uphold the heritage in the community batik tulis as Malays. Batik tulis this also pioneered by designers who have the talent and experience to make batik tulis is known with the modern concept of identity with traditional elements. In addition, batik tulis in all three premises in the Klang Valley have identity and the concept of the following over time. the effects of the study obtained by researchers will impact awareness that hand-drawn batik is not clothes traditional bad times.

\subsection{Limitation}

This research will not be generalizable to all areas in Malaysia. Focus in Klang Valley areas using Interview, Observation and Photo documentation method to collect survey from three selected batik tulis industry in Klang Valley. In addition, researchers also focused on an area of Klang valley that it had a batik producer has long been based in the Klang Valley. This is because the place selected by the research company that has formed since the beginning of the year 2000 again. In addition, also the Klang valley is also the industry that produces products batik tulis sought-after communities in the Klang Valley. Researchers also want to compare identity and concept of new batik tulis in the Klang Valley this is because there is still a lack of application of batik tulis in Klang Valley compared from Kelantan and Terengganu. In three manufacturer hand-drawn batik there have more experience about in batik making and have been operated scene ten years ago.

Klang Valley is also a place that many batik designers produce batik tulis them. In addition, also the Klang Valley also has many people who have ability to produce batik tulis. Researchers also choose batik premises in the Klang Valley which has extensive experience in the production of batik tulis. In 
the meantime, most of the designers' batik tulis this in the Klang Valley. The Klang Valley has a variety of premises batik with experience in the production of batik tulis in the Klang Valley. also be able to attract the community here to increase the adoption of batik tulis among them. In this area also the community not many know the identity and the new concept of batik tulis who became a symbol of Malay Heritage. Urban areas such as the Klang Valley also has a wide range of distinctive tastes in lifting dignity value uniquely hand-drawn batik in the Klang Valley on par with batik tulis in Terengganu and Kelantan. Researchers trying to research identity in terms of use of motifs and concepts in the design of batik tulis in three batik manufacturers.

\subsection{Scope of the Study}

In the scope of the study researchers have chosen year 2000-2018 because during the year during the year the company has been making changes to the concept of batik tulis in the Klang Valley. During the year many of these three companies that researchers' study was first established on the year. In addition, scope study taken from the year 2000 to 2018 will facilitate researchers to analyse the by year within each batik tulis issued by these three companies batik tulis. Besides that, also by making scope from 2000-2018 year will see changes to design batik tulis in terms of identity and the concept of time is now available at hand-drawn batik this in the Klang Valley. in the meantime, the company batik in Klang Valley began the change from the year 2000 with the traditional elements till the modern elements. However, the researchers will look at in the whole design hand-drawn in 2000 to 2018.

In addition, also in the year 2000 to 2018 is to appropriate year to see changes and design identity at batik tulis because it many influenced by request of the current design. In the meantime, batik tulis in the Klang Valley this element and its own identity in 2000 to 2018 in terms of identity that you are trying to get across the concepts through these batik tulis designers produce. In the year 2000 to 2018 many design company batik tulis released based on flora and abstract with modern and traditional features which form the demand among customers at the company's batik write this in the Klang Valley. They produce changes in terms of exclusive fabric with modern contemporary designs. In addition, researchers also would like to see the development of identity and the concept of changing over time but still retains the originality of batik tulis itself so that it is preserved as a heritage of the Malay community in the country. Researchers also see the change from the year 2000 to 2018 in terms of motive and identity design and batik 3 manufacturer selected.

\section{LITERATURE REVIEW}

There are many countries where batik has found a home in. For instance, the art of batik has been in Egypt and Persia for approximately 2000 years, whilst in Japan and China, it was first used in the 7th century. It has also long-existed in Indonesia, and has enjoyed growth in Malaysia since it surfaced in the country over a century ago. Kelantan and Terengganu are pioneers in the Malaysian history of batik. It began in Kota Bharu, Kelantan in 1914 when knowledge of the technique was learned in Java and brought over. Batik cloth in Malaysia was created by Haji Che Su and her friends when they worked at Batik Pelangi Enterprises, which was located at Jalan Gajah Mati, Kota Bharu. The batik industry also developed in other states in the country (Dr. Arbaiyah Aziz).

The word batik has two meanings. The word originates from Indonesia, and it means producing coloured patterns on white textiles by dyeing them. The second meaning is white cloth that is decorated with the use of wooden, copper or iron blocks, and for the areas that are to be left undyed, wax, rosin or resin is applied. Batik cloths are generally made out of cambric, lawn or voile. The art of batik is one of the cultural roots that forms the identity and raises the dignity of any given nation that batik has found a home in. The batik industry is one of the small to medium industries that form the backbone of the country. The purpose of innovating the local batik industry is to give it a chance to compete at a global level. (Batik Drawn In wax, Itie Van Hout, 2001). 


\section{RESEARCH METHODOLOGY}

This study uses the Zakaria Ali approach which has five theoretical elements, finesse (berhalus), usefulness (berguna), unity (bersatu), contrast (berlawanan), and symbolism (berlambang). In this study, researchers have been in the interview with three batik tulis related manufacturers around the Klang Valley. In addition, qualitative methodology has been a suitable method for making interviews with three batik tulis manufacturers around the Klang Valley. Besides that, in conducting this interview a number of designers and batik tulis makers have been taken to be collected from the study data. Apart from that, some academicians have expertise in the batik tulis have been selected for the first objective. On the whole, convenience sampling was employed due to a small population in the Klang Valley area. The conceptual framework contains global themes such as uplift appreciation and awareness of local motif and design of batik tulis identity. All these batik studies will follow the theory founded by Zakaria Ali.

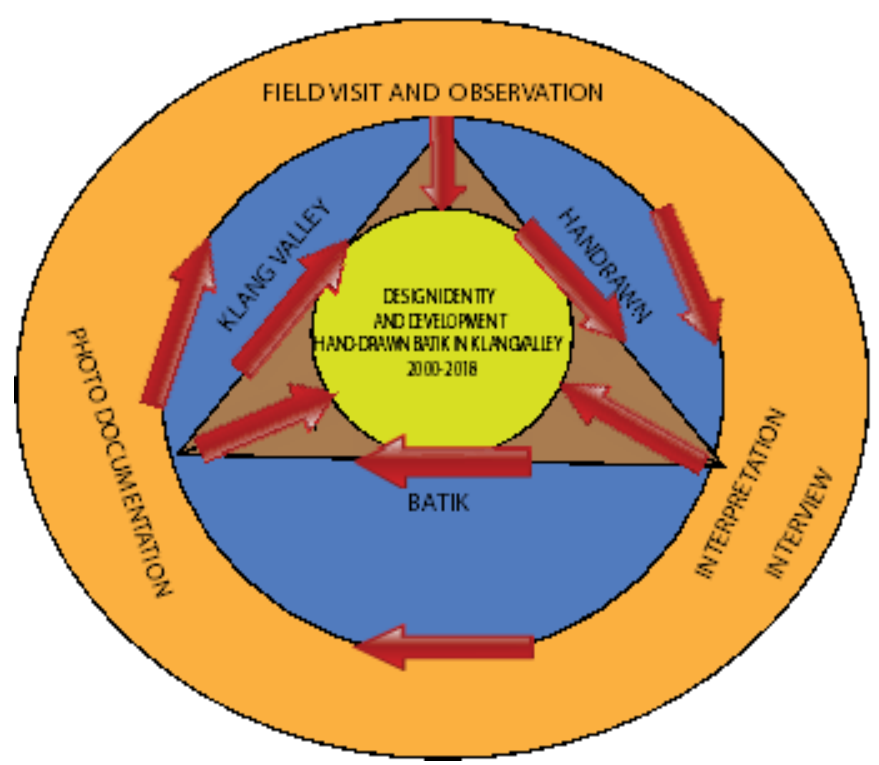

Figure 1: Research framework design identity and development batik Tulis in Klang Valley from 2000-2018

\subsection{Flow Chart of the Study}

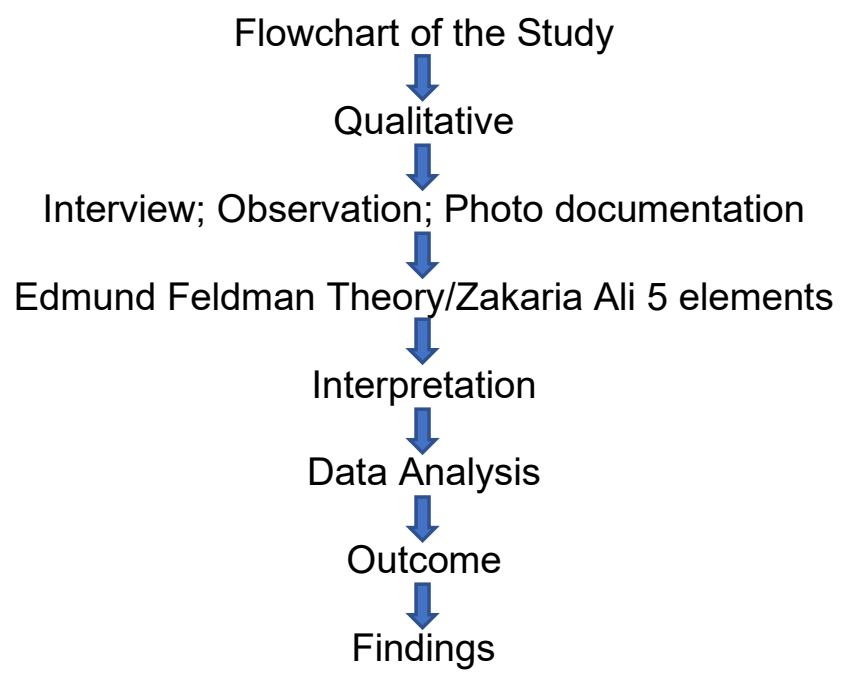




\section{DATA ANALYSIS}

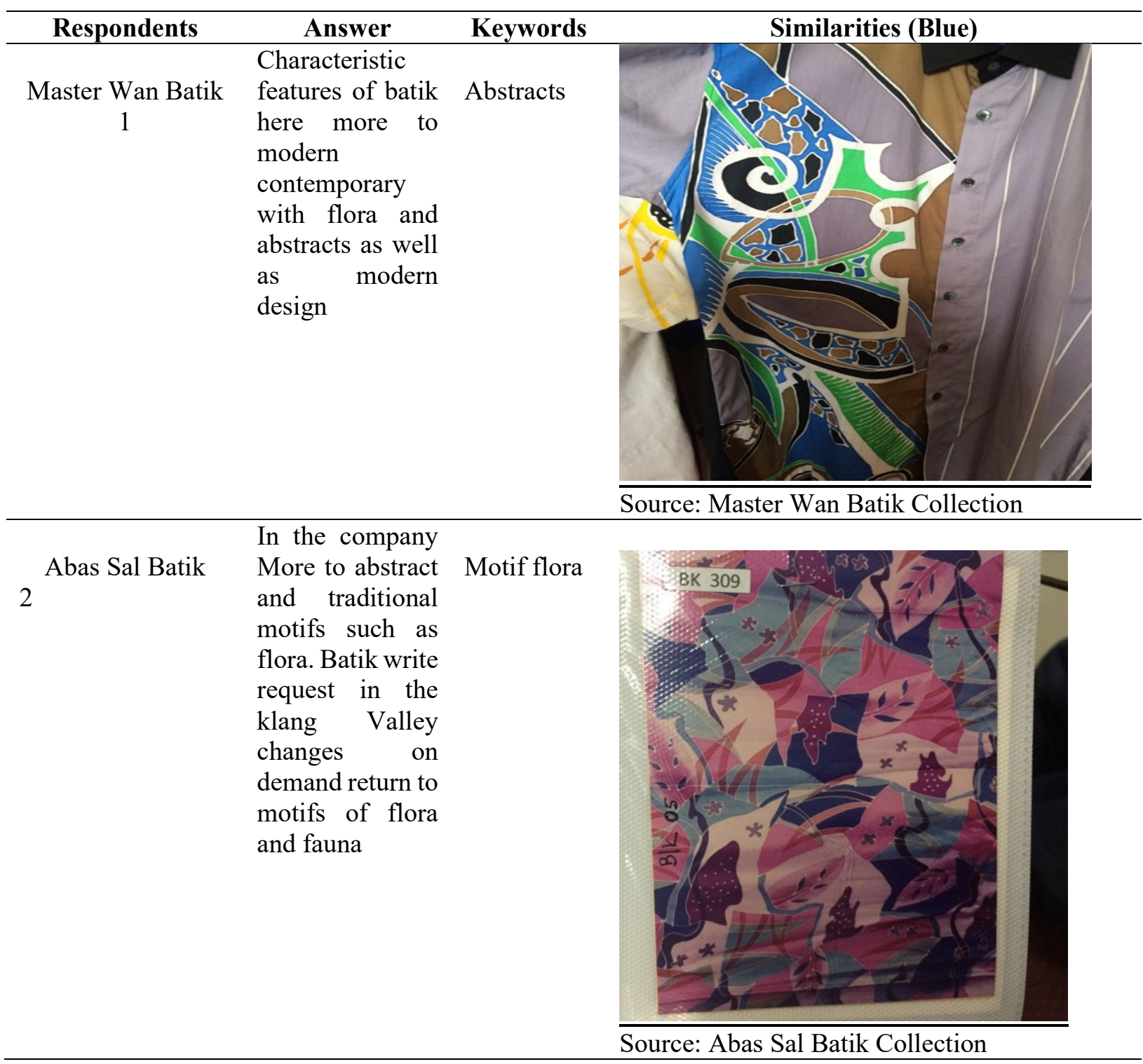




$\begin{array}{cl}\text { Chanting } & \text { Characteristics } \\ \text { Creation } & \text { of batik here it } \\ 3 & \text { much to the } \\ & \text { modern pattern } \\ \text { of flora on } \\ \text { demand } \\ \text { customer of } \\ \text { batik. In } \\ \text { addition, the } \\ \text { characteristics } \\ \text { of the batik is } \\ \text { also more to } \\ \text { design batik } \\ \text { fans want to } \\ \text { abstracts at } \\ \text { varieties every } \\ \text { year. }\end{array}$

Flora yang
moden

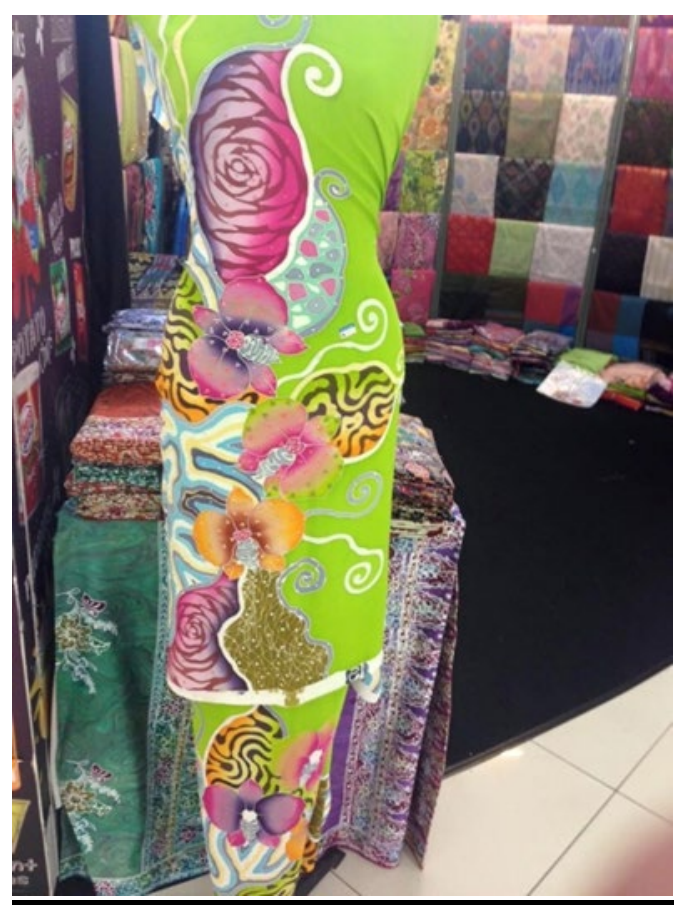

Source: Chanting Creation Collection

\subsection{Result and Discussion}

\subsubsection{Master Wan Batik Collection}

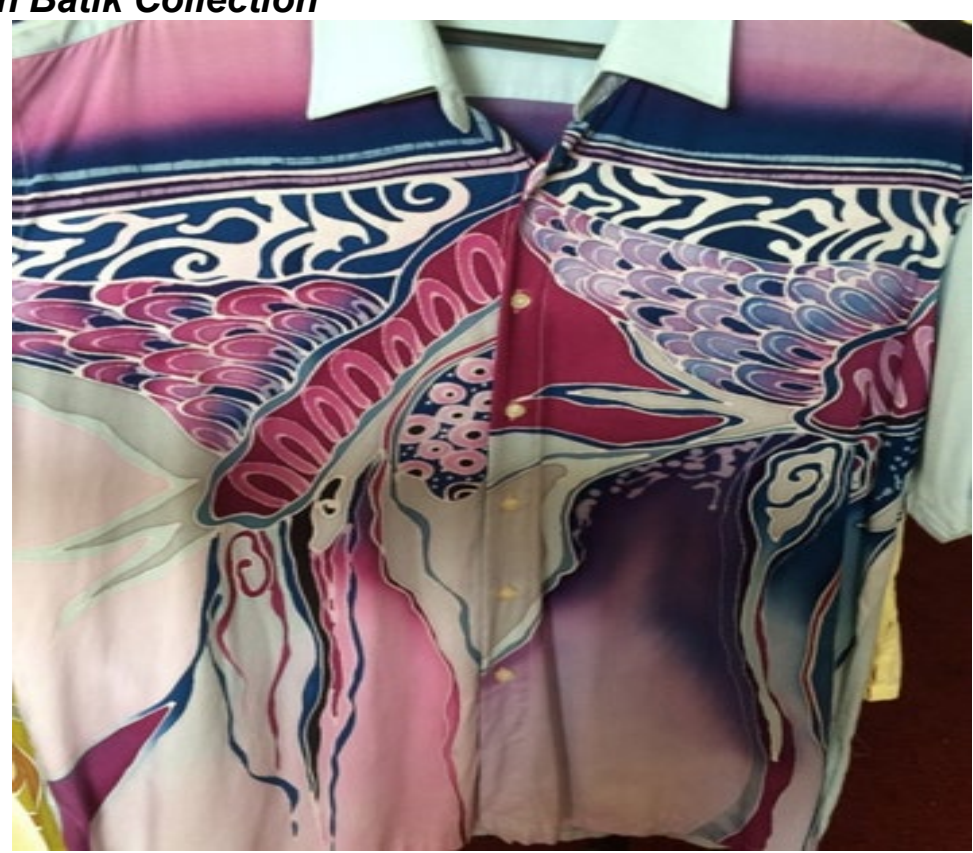

Figure 2: Batik Tulis Master Wan Batik 2000-2005

Based on the above batik designers using Peacock motif artwork above batik tulis fabric. Peacock also has an interesting pattern that is the pattern of fur with colours Blue, red, this is interesting. This is because the birds they are symbols of animals in this country. In addition, the Peacock was animal or subject matter that lives in Malaysia and countries such as Bangladesh, India and others. In addition, batik tulis, this pattern flaps peacocks reworked from original motifs. Designers have been making with the size different between canting outlines motif with lines in the motif. This is because the size of the canting sizes used showed the designer to emphasize in batik tulis this designer due to the statement 
Zakaria Ali, (1993) in the production of this art, many things should be taken into consideration to achieve fine arts such as shapes, structures, balances, compositions, colours and themes. In this writing explained that the designers emphasised the elements of composition between the left and the right at the figure section above.

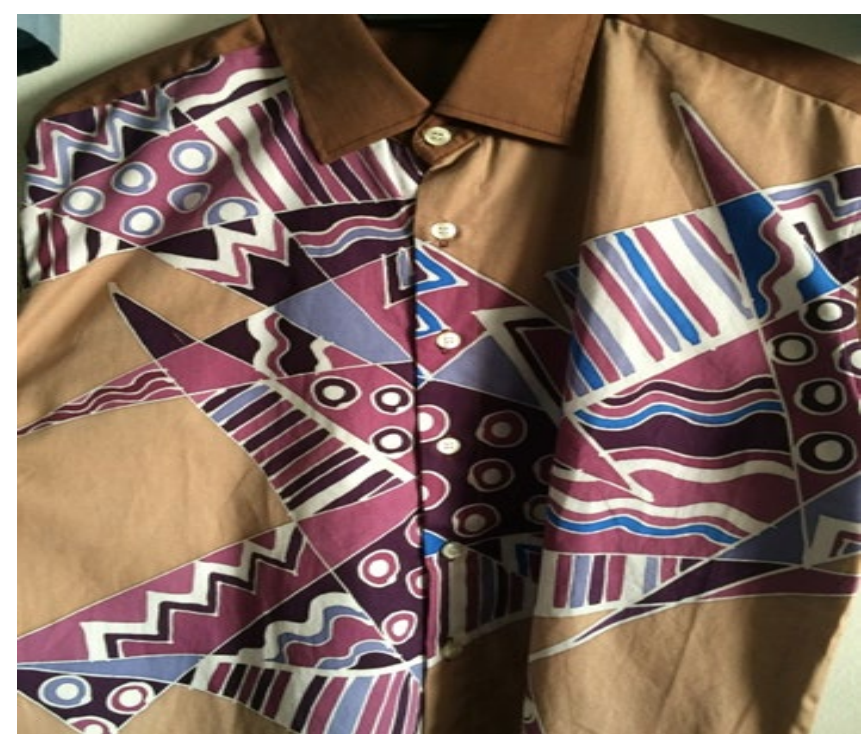

Figure 3: Batik Tulis Master Wan 2005-2008

Batik pattern design more to in these batik tulis more to geometric-shaped for example. triangles, rounded, straight lines and undulating lines. In addition, these patterns of batik tulis rather have straight line and corrugated lines. This geometric motifs in spell because its requirement patience to manufactured by using the canting. This is because of geometric shapes require a very high concentration. In the product Master Wan Batik, batik designers this this using canting line style straight above this, as well as round, corrugated line.

In the production of this writing, it is more to the geometric pattern with various patterns of this pattern, however, it is more independent and more than not limited to the pattern of flora and fauna but also the pattern of more geometric with cold colour. and bright. Based on statement Moore (1942) It is suggested that the value of the beauty of the form can be measured by angle, i.e., objective and subjective. From the objective corner, the evaluated features are such a form of object or work. The form works more focused on real aspects based on design elements such as colours, outer shapes (shape), lines, texture, etc. 


\subsubsection{Abas Sal Batik Collection 2000-2018}

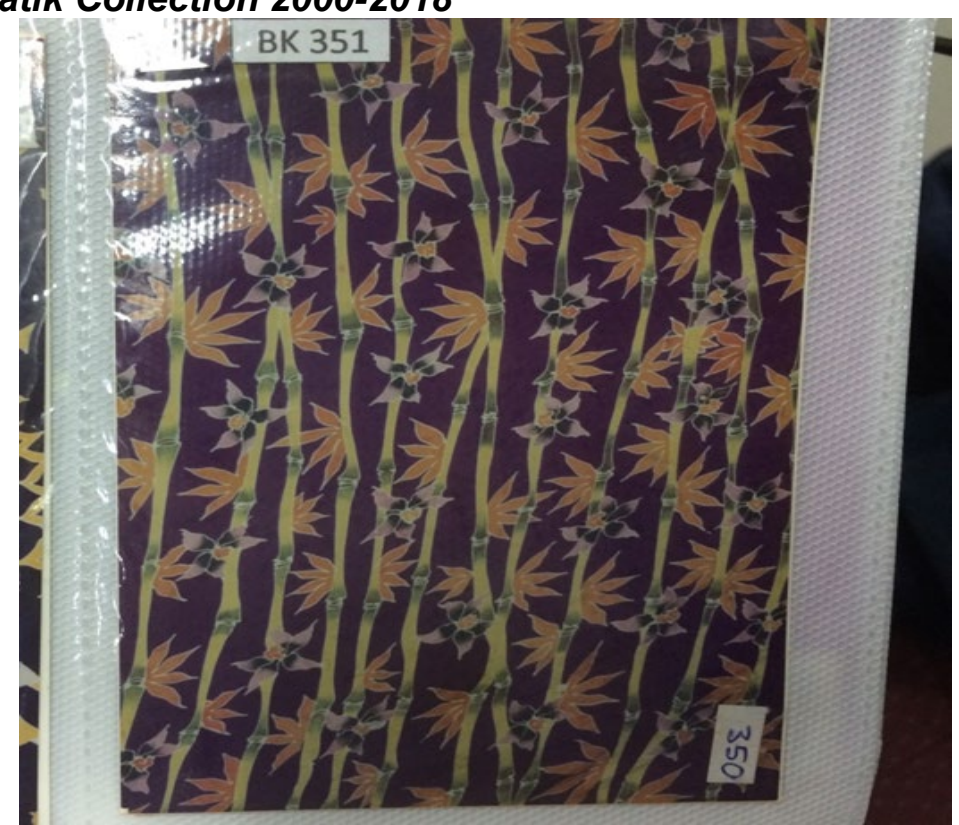

Figure 4: Batik Tulis Abal Collection 2005-2009

In this designer using batik tulis subject matter of bamboo as an idea in the motif of batik tulis around 2005-2009. This batik tulis is with modern colours and still maintains the traditional concept that is a repetitive design. Designers use the subject matter as it is easy to find and also it has a uniquely distinctive in terms of appearance and attractive to be used as motifs in batik tulis at Abas Sal this batik tulis. In this subject matter to bamboo, batik motif support in this whole space in this batik. Colours used in batik are also modern colors.background color darker than the color motif would give an impact on subject matter that used this. the color used is the color purple, orange, green, yellow, purple, namely modern colors.

In these work batik tulis di Abas Sal Batik it is more susceptible to more organic ideas to plants, which are around us and it is easily reachable to our environment and also has an interesting look. This was also explained as Zakaria Ali, (1987) The natural ingredients of nature are the most important level of experience for the Malays. The rich and beautiful nature of the environment became the attraction to the Malay artist to make it necessary for their needs and to do things. The value of aesthetics produced is something that has an aesthetics value. The value of aesthetics produced in the crafts of these Malays is subtle, useful, united, fighting, and principles of the emblem so that they can provide satisfaction to the designer and craft of crafts and art. 


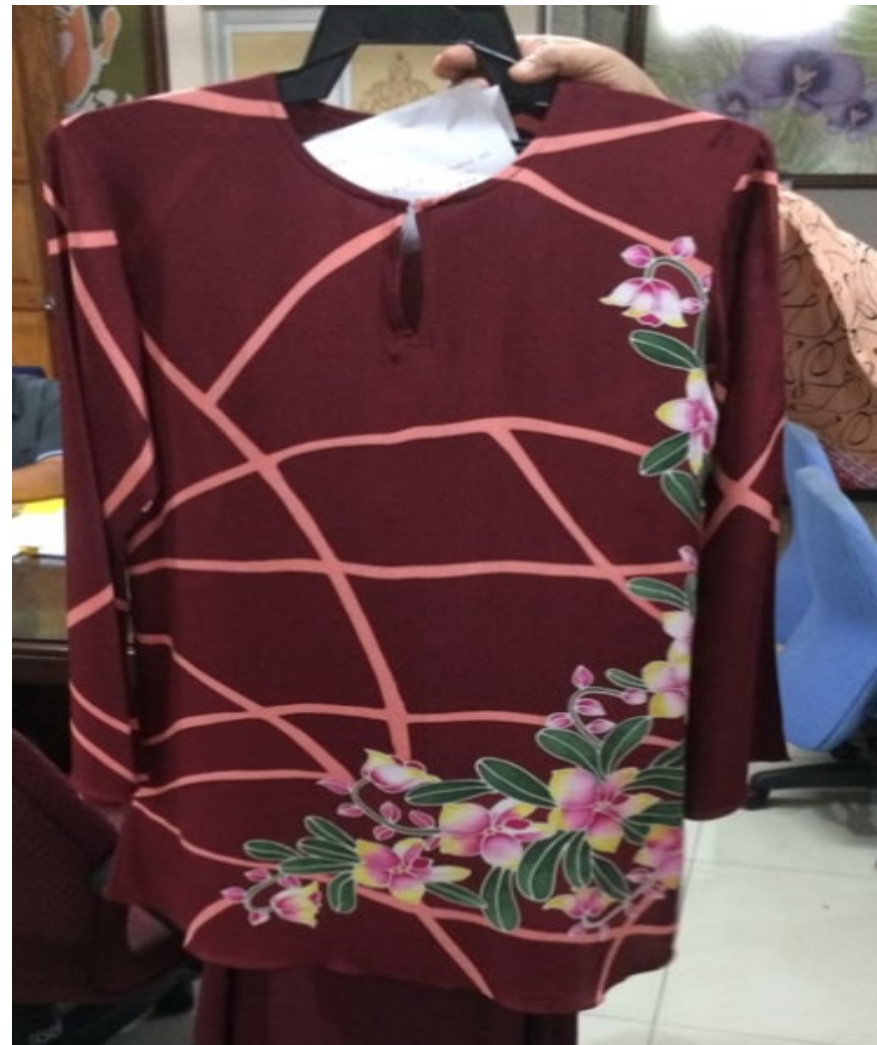

Figure 5: Batik Tulis Abas Sal Batik 2015-2018

Design batik tulis in batik this company Abas Sal Batik more highlighting the concept of flora but have become the modern use of contemporary colors.In the meantime, this design hand-drawn batik at this bracket has been the shirt with brush techniques which are used as background on fabric this baju kurung. The designer batik in batik applied Abas Sal colours such as purple, yellow, green, pink, dark red batik tulis at this fabric using composition layouts at the bottom of the subject matter of this flora. the size of this Orchid flowers are also different and are arranged closely among each other.

Batik tulis in the Abal Sal Batik, this has a pattern of orchid flowers, which means the softness that reflects the pattern of attitude in our daily lives. This is because by Ku Zam Zam,(1984), The surroundings is something that is an important resource in the production of the Malay motifs. Most of the patterns produced by Malays usually have a connection between their lives and the environment. In relation to this, the production of Malay crafts is less than a sense of awareness of the needs of applied and aesthetics or life. It is therefore imperative that the idea of the environment has also played an important role in valuing flora and fauna as long as it is still because it is a inspiration source of designers and these artwork batik tulis. 


\subsubsection{Chanting Creation Collection 2000-2018}

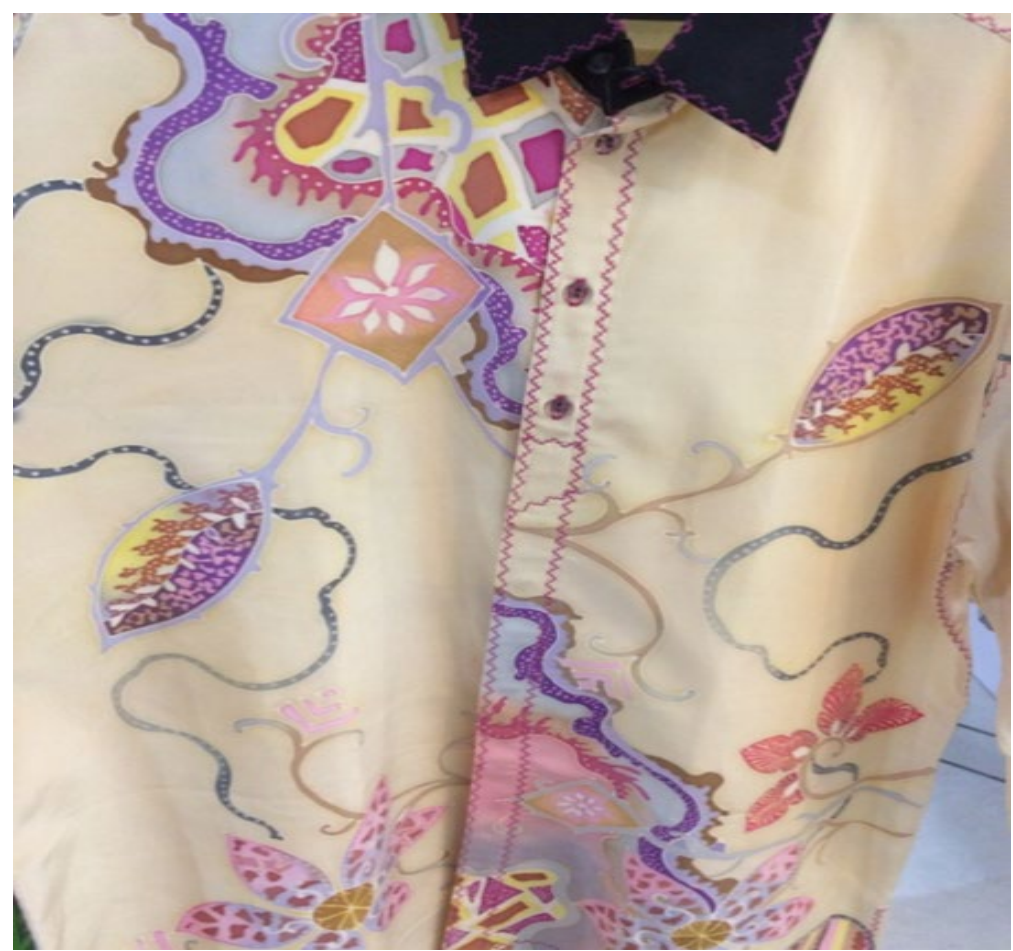

Figure 6: Batik Tulis Chanting Creation 2005-2009

In this designer took a hand-drawn batik inspiration from subject matter to flora to be used as motifs in batik shirt. Then, this batik tulis motif in this more towards users with modern colours. The designer also uses modern colour in this batik tulis. Colour in the batik tulis is more emphasized colours not like traditional batik but more to contemporary. In this designer using batik tulis details on subject matter this batik tulis . Designers use the subject matter of the main motif as motifs highlighted in this handdrawn batik. Colour used also such as purple, orange, Brown, red and blue.

In these batik tulis design these use gentle colours as well as leaf motifs or flora that provide peace of colour that affects the psychology of the batik lovers and their favour. Pursuant to the statement Pooke \& Witham, (2010) in the art of painting, visual elements including lines, shapes, colours and tones are embodied from the effects of the technique and media used by the artist. Meanwhile, Collingwood, (1984) to evoke certain feelings among observers such as the purpose of an artist arouse of certain kind of action. 


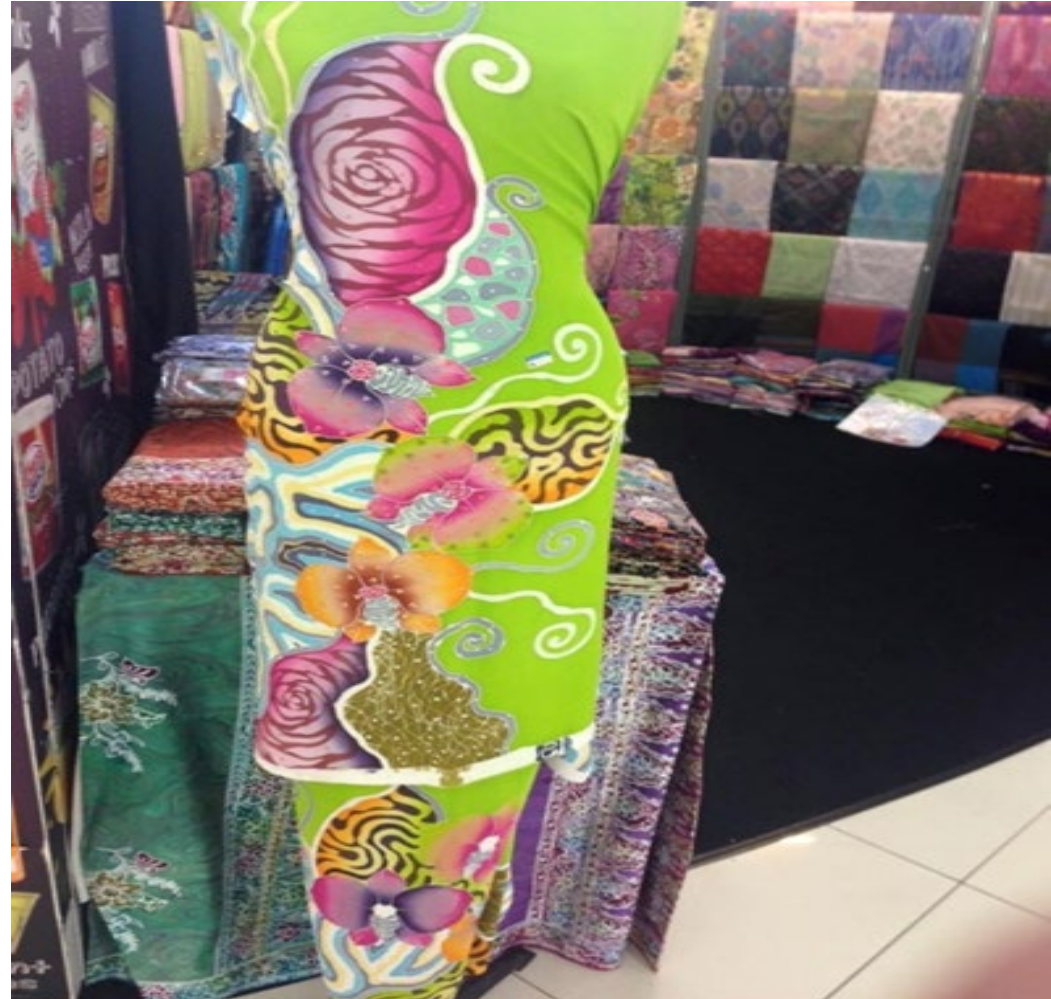

Figure 7: Batik Tulis Chanting Creation 2010-2014

Designers take inspiration subject matter of butterflies' fauna in batik motif as in collection of Chanting Creation produced in 2010-2014 here. Batik here in modern looks with modern colours with the colour tones on the subject matter of this butterfly. Then, the composition of this support motives also plays a role to not seem too lost space to the main motif in batik tulis this. The colour used is also modern and also harmony. Batik tulis is more identity to produce motive flora and in variation in the form of modern and contemporary. The designer also generates a motif by maintaining the concept of flora and fauna but be modern with focus on motive's main produce.

From Rabiatuladawiyah Mohd Kari et.al, (2018) researched stated is the philosophy of fauna in batik artwork has been affected. Globalization has affected the basic meaning of values, metaphor, and symbol, in Malay attire such as batik. Furthermore, butterfly, bees, bird motifs, cock, peacock, deer, and mousedeer are also other important included, whereby the motifs were changed in the organic style that had symbolic values.

In the $20^{\text {th }}$ century, the making of Malaysian batik had introduced a new tradition to the Malaysians, whereby the batik types and motifs became the national symbol to retain its original values to be protect and inherited by the society that understands its values. Moreover, the awareness of the significance of batik tulis sustainability and preservation has contributed to the rapid progress of batik tulis. Besides, the manufacturers' batik, which is vital symbol that was completely threatened, and now protected by the government as all Malaysians have a similar understanding of batik tulis. 


\subsection{Findings from the Keywords of Interviews}

\author{
Respondents \\ Master Wan \\ Batik \\ 1
}

Abas Sal Batik

2

\begin{abstract}
Chanting
Creation

3
\end{abstract}

\begin{abstract}
Answer
Kelantan batik Terengganu over to a use of colour and design that design the old one too many flora and repetitive design. batik Klang valley there is assertion of contemporary design
\end{abstract}

In addition, also write in Klang valley batik more to the modern use of colour, abstract, geometric and a bit of flora and fauna assertion at design batik this hand drawn. batik in Kelantan and Terengganu over to colour that stands out and not a lot geometric pattern to date.

\begin{abstract}
Batik Kelantan and Terengganu use of colour more harmonious. batik in the Klang Valley this colour more to contemporary modern and more focus on batik shirt and products such as hand bag included batik pattern.
\end{abstract}

\author{
Keywords \\ Batik Kelantan more \\ focused on many \\ colours \\ Batik Klang Valley \\ there is assertion of \\ batik design
}

\begin{abstract}
Batik Klang Valley focus on abstract, modern use of colour and depth with design.

Kelantan batik to more subtle colours
\end{abstract}

Batik Kelantan and Terengganu more use of colour harmony Batik Klang Valley focus on modern contemporary design

\author{
Similarities \\ Colour \\ attestations
}

Modern echoes colour

\section{Colour harmony Modern contemporary}

\section{CONCLUSION}

As a result of, this learning will identify identity concept of batik tulis at three premises of batik in the Klang Valley from the year 2000 to 2018. Batik tulis at three premises had a distinctive identity in terms of concepts, including the use of colour, fabric type, layout and composition of the subject matter. From this study batik designers also write in three other premises this produce identity concept motifs in batik tulis from year 2000 to 2018. As a result, all of the findings were analysed using the Theory approach of design Analysis, and interpretation. Production of batik tulis in the Klang Valley has changed from traditional patterns to modern concepts of identity. All three companies' batik tulis similarity identity concept from the year 2000 to 2018. Results from the study also researchers get identity batik tulis in the Klang Valley have a modern concept in which it still retains features motifs of flora and more modern use of colour composition also subject matter as the key motive in display on the product of batik tulis at three premises this batik.

\section{REFERENCES}

Adi Taha. 1991. Perkembangan Sejarah Awal Negeri Kedah, Berdasarkan Penemuan Bahan-bahan Arkeologi dlm Dokumentari Konvensyen Sejarah Negeri Kedah, hlm.20-28.

Ahmed, N. Y. N. 2015. Sumbangan Che Su dan keluarga kepada pembangunan perusahaan batik di Kelantan (Doctoral dissertation, University Malaysia Kelantan). 
Akhir, N. H. M., Ismail, N. W., Said, R., Ranjanee, S., \& Kaliappan, P.2015. Traditional craftsmanship: The origin, culture, and challenges of batik industry in Malaysia. In Islamic perspectives relating to business, arts, culture and communication (pp. 229-237). Springer, Singapore.

Arbaiyah Aziz.2008. Menelusuri Tradisi Seindah seni Semurni Budaya dan Warisan Sepanjang Zaman,Batik Merbok, MPH Group Publishing Sdn Bhd, Petaling Jaya,Selangor, PTAR UITM Shah Alam

Dharmarajan, N., Aziz, A. A., \& Lokman, A. M. (2006). Archiving cultural heritage in Malaysia: The Nyonya kebaya. In Proceedings of the International Conference on Business Information Technology (p. 13).

Drs,Biranul Anas.2008.Batik, Sekretariat Tim Penyusun Seri Buku Museum Grafika,Jakarta Pusat,Indonesia,PTAR UITM Shah Alam.

Fiona Kerlogue. 2004. The Book Of Batik,Archipelago Press, an imprint of Editions Didier Millet 121 Telok Ayer Street, Singapore,068590,PTAR, UITM Shah Alam.

Hidayat, J., \& Fatmahwaty, F. 2014. The Art and Sustainable Aspects of Natural Dyeing in KANAWIDA Hand Drawn Batik (Green Batik). IPTEK Journal of Proceedings Series, 1(1).

Hidayat, S. R..2018, February. Innovation of Hand-Drawn Batik in Context of Tourism. In 4th Bandung Creative Movement International Conference on Creative Industries 2017 (4th BCM 2017). Atlantis Press.

Itie Van Hout. 2001. Batik Drawn in Wax, KIT publishers-Amsterdam, PTAR UITM Shah Alam.

Kari, R., Samin, A., \& Legino, R. (2018). The Sustainability's Motif and Design of Fauna in Malay Block Batik. In International Conference on Social Sciences, Humanities, Economics and Law. European Alliance for Innovation (EAI).

Khairi, A., Hamid, S. E. A., \& Ismail, S. B. 2018. Penonjolan Identiti Budaya Melayu Menerusi Aplikasi Batik dalam Pembuatan Bot Gentian Kaca (Fibreglass Boat) di Universiti Kuala Lumpur Malaysian Institute of Marine Engineering Technology (UniKL MIMET), Lumut, Perak. Wacana Seni Journal of Arts Discourse, 17.

Mangifera, L. 2016. Pengembangan Industri Kreatif Produk Batik Tulis Melalui Value Chain Analysis.

Noorizan, M. F., Ramli, I., \& Nawawi, N. M. 2015. The Exploration Technique of Nature for Contemporary Batik Design. In International Colloquium of Art and Design Education Research (iCADER 2014) (pp. 277-287). Springer, Singapore.

Rahmah Bujang dan Nor Azlin .2002. Kesenian Melayu,Kuala Lumpur:Akademik Pengajian Melayu,Universiti Malaya.

Rahman, R. A. 2013. CULTURAL CONFLICT AND RESOLUTION BETWEEN INDONESIA AND MALAYSIA: THE GOVERNMENT EFFORT TO RESPOND BATIK CLIMED BY MALAYSIA IN 2009 (Doctoral dissertation, President University).

Samin, M. A., Ramli, N. A., \& Legino, R. 2017. Designing batik with alternative batik techniques using wax application. Advanced Science Letters, 23(11), 10629-10631.

Sekimoto, T.2003. Batik as a Commodity and a Cultural Object. New York: Berghan Books.

Siti Zainon Ismail,Tekstil Melayu .1994. Fungsi Simbol dan Keindahan.Dalam Ismail Hussein, A.Aziz Deraman dan Abd. Rahman Al-Ahmadi,Tamadun Melayu Jilid Lima (hlm.2035-2055) Kuala Lumpur:Dewan Bahasa dan Pustaka.

Siti Zainon Ismail.1986. Rekabentuk Kraftangan Melayu Tradisi.Kuala Lumpur: Dewan Bahasa dan Pustaka.

Steelyana, W. 2012. Batik, a beautiful cultural heritage that preserve culture and support economic development in Indonesia. Binus Business Review, 3(1), 116.

Wisnalmawati, W., Surachman, S., Rahayu, M., \& Hussein, A. S. (2015). Brand Prestige as Mediation Effect of Store Image on Store Loyalty (Study of Batik Tulis Store Customer at Yogyakarta Special Region). Australian Journal of Basic and Applied Sciences, 9, 635-641.

Yunus, N. A. 2012. Malaysian batik: Reinventing a tradition. Tuttle Publishing. 